\title{
Pengaruh Pemberian Kompres Larutan Jahe Terhadap Nyeri Asam Urat Di Posyandu Lansia Melati Desa Candisari
}

\author{
Suryani $^{1}$, Sutiyono ${ }^{2}$, Mingle A Pistanty ${ }^{3}$ \\ ${ }^{1,2,3}$ Program Studi D III Keperawatan, Universitas An Nuur \\ Email: suryanilatifa@gmail.com; mstiono@gmail.com; minglepistanty@gmail.com
}

\begin{abstract}
ABSTRAK
Asam urat merupakan penyakit yang diakibatkan tingginya kadar purin di dalam darah. Di Dunia asam urat meningkat dua kali lipat populasi $>75$ tahun, saat ini di Indonesia di lihat dari karakteristik umur dan jenis kelamin , prevalensi tertinggi umur $>75$ tahun $(54,8 \%)$. Penderita wanita juga lebih banyak $(27,5 \%)$ di bandingkan dengan pria (21,8\%).Diperlukan suatu tindakan nonfarmakologi untuk mengurangi nyeri sendi pada lanjut usia, salah satunya adalah terapi nonfarmakologi kompres larutan jahe. Penelitian ini bertujuan untuk mengetahui pengaruh pemberian kompres larutan jahe (zingiber officinale roscoe) terhadap nyeri asam urat di Posyandu Lansia Melati Desa Candisari Kabupaten Grobogan. Metode dalam penelitian ini menggunakan desain penelitian Quasi Eksperimental dengan pretest-posttest with control group design. Teknik sampling yang digunakan adalah noprobability sampling dengan pendekatan total sampling dan didapatkan sampel berjumlah 50 responden. Hasil analisa pengaruh ditujukan dengan adanya pengaruh tingkat skala nyeri sebelum dan setelah dilakukan pemberian kompres larutan jahe menggunakan uji statistik paired $\mathrm{t}$ test, didapatkan nilai signifikasi sebesar 0,0001 atau kurang dari $0,05(\mathrm{p}<0,05)$, dengan nilai t sebesar 39.192. Kesimpulan dari hasil penelitian tersebut ada pengaruh pemberian kompres larutan jahe (zingiber officinale roscoe) terhadap nyeri asam urat di Posyandu Lansia Melati Desa Candisari Kabupaten Grobogan.
\end{abstract}

Kata Kunci : Asam urat, Jahe, Nyeri

\section{ABSTRACT}

Gout is a disease caused by high levels of purines in the blood. In the world uric acid has doubled in population> 75 years, currently in Indonesia, in terms of age and sex characteristics, the highest prevalence is $>75$ years (54.8\%). There were also more women (27.5\%) compared to men (21.8\%). A non-pharmacological action is needed to reduce joint pain in the elderly, one of which is non-pharmacological compressing ginger solution. This study aims to determine the effect of applying ginger (zingiber officinale roscoe) compresses to gout pain at the Posyandu for the Elderly Melati, Candisari Village, Grobogan Regency. The method in this study used a Quasi-Experimental research design with a pretest-posttest with control group design. The sampling technique used was noprobability sampling with a total sampling approach and obtained a sample of 50 respondents. The results of the influence analysis were aimed at the influence of the level of pain scale before and after giving compresses of ginger solution using the paired t test statistical test, obtained a significance value of 0.0001 or less than 0.05 ( $p$ $<0.05$ ), with a $t$ value of 39.192. The conclusion from the results of this study is that there is an effect of applying a compress of ginger (zingiber officinale roscoe) solution to gout pain at the Elderly Melati Posyandu, Candisari Village, Grobogan Regency.

Keywords : Gout, Ginger, Pain 


\section{LATAR BELAKANG}

Asam urat merupakan penyakit yang diakibatkan tingginya kadar purin di dalam darah (Alifiasari, 2011). Asam urat disebabkan adanya penumpukan kristal-kristal yang merupakan hasil akhir dari purine, dimana ginjal tidak mampu mengeluarkan asam urat melalui urin sehingga membentuk kristal yang berada dalam cairan sendi sehingga menyebabkan penyakit asam urat (Nopik, 2013).

Berdasarkan data dari World Health Organisation (WHO) pada tahun 2016 dalam Jaliana, 2018 prevalensi asam urat di Amerika Serikat sekitar 13,6 kasus per 1000 laki-laki dan 6,4 kasus per 1000 perempuan. Kadar asam urat yang normal menurut WHO pada lakilaki dewasa adalah sekitar 2-7,7 $\mathrm{mg} / \mathrm{dl}$, sementara itu pada wanita yang sudah dewasa adalah 2-6,5 mg/dl. Berdasarkan penelitian (Dalimartha, 2010), di Indonesia asam urat menduduki urutan kedua setelah osteoarthritis. Jika dilihat dari karekteristik umur, prevalensi tertinggi pada umur $\geq 75$ tahun $(54,8 \%)$. Penderita wanita juga lebih banyak $(27,5 \%)$ dibandingkan dengan pria $(21,8 \%)$. Prevalensi penderita asam urat yang paling tinggi yaitu di Bali yang mencapai 19,3\%. Di Sulawesi Utara juga merupakan salah satu prevalensi tertinggi penderita asam urat yaitu mencapai 10,3\% (Hamijoyo, 2014).

Di Jawa Tengah prevalensi penyakit asam urat didapatkan prevalensi asam urat sebesar 24.3\% (Nengsi, 2014). Berdasarkan data dari Dinas Kesehatan Kabupaten Grobogan tahun 2018 didapatkan hasil angka kejadian asam urat di Puskemas Purwodadi 1 tergolong tinggi yaitu terdapat 1020 kasus. Salah satu tanda yang dialami oleh penderita asam urat adalah nyeri. Dampak nyeri sendi adalah penurunan kualitas harapan hidup seperti kelelahan yang begitu hebatnya, menurunkan batasan gerak tubuh dan nyeri saat bergerak. Kekakuan bertambah berat pada pagi hari pada saat bangun tidur, nyeri yang hebat pada awal gerakan akan tetapi kekakuan tidak berlangsung lama yaitu kurang lebih seperempat jam. Kekakuan di pagi hari menyebabkan berkurangnya kemampuan gerak dalam melakukan 4 gerak ekstensi, keterbatasan mobilitas fisik dan efek sistemik yang di timbulkan adalah kegagalan organ dan kematian (Price, 2012).

Dalam menangani nyeri sendi pada lanjut usia, perlu penanganan yang tepat baik secara farmakologi maupun nonfarmakologi. Penanganan secara farmakologi akan diberikan obat antiinflamasi nonsteroid (NSAID) dalam menghalangi proses produksi mediator peradangan (Arya and Jain, 2013). Terapi nonfarmakologi adalah tindakan dalam batas keperawatan yang dapat digunakan untuk menurunkan nyeri sendi. Adapun terapi nonfarmakologi yang dapat digunakan dalam menurunkan nyeri sendi antara lain: bimbingan antisipasi, distraksi, biofeedback, hipnosis diri, masase kulit, relaksasi dan kompres. Kompres hangat yang bertujuan untuk menstimulasi permukaan kulit yang mengontrol nyeri (Prasetyo, 2010). Salah satu bahan untuk kompres yang dapat memberikan sensasi hangat adalah jahe. Kandungan jahe bermanfaat untuk mengurangi nyeri pada asam urat karena jahe memiliki sifat pedas, pahit dan aromatik dari olerasin seperti zingeron, gingerol, dan shagaol. Olerasin memiliki potensi anti inflamsi, analgetik dan antioksidan yang kuat. Olerasi atau zingerol dapat menghambat sintesis prostalglandin sehingga padat mengurangi nyeri atau radang.

Menurut Rusnoto pada tahun (2015), teknik kompres hangat memakai jahe yaitu jahe 100 gram yang telah diparut diletakkan diatas washlap yang sudah dicelupkan pada air panas sekitar 500 cc yang bersuhu sekitar $40^{\circ} \mathrm{C}$, setelah itu kompres pada daerah yang 
nyeri 20 menit selama 2 kali. Penelitian lain dilakukan oleh Samsudin pada tahun (2016), didapatkan bahwa pemberian kompres jahe berpengaruh terhadap instensitas nyeri asam urat pada lansia. Berdasarkan munculnya berbagai macam penyakit yang diderita oleh lansia, maka pemerintah membuat suatu progam kesehatan masyarakat yaitu posyandu lansia. Posyandu lansia merupakan suatu pos pelayanan terpadu untuk masyarakat lanjut usia di suatu wilayah tertentu yang sudah disepakati dan digerakkan oleh masyarakat dimana mereka bisa mendapatkan pelayanan kesehatan (Handayani \& Wahyuni, 2012).

Pada wilayah Puskesmas Purwodadi 1 terdapat 8 progam posyandu lansia yang tersebar di 9 desa, Desa Candisari merupakan salah satu Desa yang memiliki program posyandu lansia dengan jumlah lansia yang terdaftar sebanyak 111. Aplikasi kompres di Posyandu Lansia merupakan terapi eksternal tanpa ada efek yang merugikan klien. Jahe juga mudah dijumpai didaerah. Prevalensi penderita asam urat yang setiap tahun semakin meningkat di Desa Candisari memerlukan penanganan serius, salah satu teknik terapi yang bisa dilakukan di lingkungan masyarakat yaitu kompres larutan jahe yang mudah diterapkan sehingga tujuan akan tercapai yaitu nyeri sendi akan berkurang dengan cara tradisional untuk mengatasi nyeri sendi pada saat asam urat kambuh dan tidak ketergantungan terhadap obat dari dokter maupun Puskesmas.

\section{METODE PENELITIAN}

Penelitian ini menggunakan desain penelitian Quasi Eksperimental dengan pretestposttest with control group design yaitu menggunakan kelompok perlakuan dan kelompok kontrol sebagai pembanding (Sugiono, 2012). Teknik sampling yang digunakan adalah noprobability sampling dengan pendekatan total sampling dan didapatkan sampel berjumlah 50 responden di Posyandu Candisari.

Pengumpulan data selama 3 minggu dan pengukuran dengan menggunakan skala Bourbanis yang di awali pemeriksaan kadar asam urat. Penelitian ini telah di uji etik di RSUD Purwodadi dan lansia yang berperanserta dalam penelitian memahami dan penyetujui menjadi responden. Analisis data pada kelompok berpasangan menggunakan uji paired $t$-tes sedangkan pada analisis antara kelompok perlakukan dan kelompok control menggunakan uji independent $t$ - tes

\section{HASIL DAN PEMBAHASAN}

\section{Hasil Penelitian}

Hasil analisis penelitian didapatkan, pada analisa karakteristik responden sebagian besar responden berjenis kelamin laki- laki, kelompok umur didominasi usia 64 tahun, pendidikan terakhir paling banyak lulusan SD dan pekerjaan responden sebagian besar adalah petani. Hasil analisa univariat pada kelompok perlakuan sebelum dilakukan kompres larutan jahe diperoleh hasil sebagian besar nyeri sedang dan setelah dilakukan perlakuan di dapatkan hasil nyeri ringan. Pada kelompok kontrol sebelum diberikan kompres air hangat diperoleh hasil sebagian besar nyeri sedang dan setelah dilakukan perlakuan di dapatkan hasil nyeri ringan dengan prosentase lebih kecil penurunannya 
dibandingkan dengan kelompok perlakuan. Pada hasil analisa bivariat diperoleh rata- rata penurunan nyeri 3.2 dan hasil nilai signifikansi dari perbedaan tersebut didapatkan $p$ $(0.0001)<\alpha(0.05)$ yang artinya ada pengaruh kompres larutan jahe terhadap nyeri asam urat.

\section{Hasil Analisa Bivariat \\ Pengaruh Pemberian Kompres Larutan Jahe Terhadap Nyeri Asam Urat Kelompok Perlakuan}

Tabel 1 Pengaruh Pemberian Kompres Larutan Jahe Terhadap Nyeri Asam Urat

\begin{tabular}{lllll}
\hline Variabel & Mean & SD & Nilai t & Sig. (2-tailed) \\
\hline Pre kompres larutan jahe & 5.64 & 1.551 & 39.192 & 0.0001 \\
Post kompres larutan jahe & 2.44 & 1.417 & 39.192 & 0.0001 \\
Rata-rata penurunan nyeri & 3.2 & 0.408 & 9.899 & 0.0001 \\
\hline
\end{tabular}

Berdasarkan uji statistik dengan menggunakan paired t test kelompok perlakuan pada nyeri asam urat didapatkan nilai rata-rata nyeri sebelum dilakukan pemberian kompres larutan jahe adalah 5.64, dan nilai rata-rata setelah dilakukan pemberian kompres larutan jahe adalah 2.44, artinya ada perbedaan nyeri sebelum pemberian kompres larutan jahe dan nyeri setelah pemberian kompres larutan jahe. Nilai signifikansi dari perbedaan tersebut didapatkan $p(0.0001)<\alpha(0.05)$ pada taraf kepercayaan 95\%, Maka dapat disimpulkan Ada Pengaruh Pemberian Kompres Larutan Jahe Terhadap Nyeri Asam Urat Di Posyandu Melati Desa Candisari Kabupaten Grobogan.

Berdasarkan hasil statistik didapatkan nilai t untuk kelompok perlakuan kompres larutan jahe sebelum dan setelah perlakuan sebesar 39.192 dan nilai t untuk rata-rata penurunan nyeri kelompok perlakuan kompres jahe sebesar 9.899. Berdasarkan uji statistik dengan menggunakan uji independent $t$ test diperoleh nilai rata-rata penurunan nyeri asam urat pada kelompok perlakuan kompres larutan jahe sebesar 3.20.

Pengaruh Kompres Hangat Terhadap Nyeri Asam Urat Pada kelompok Kontrol .

Tabel 2 Pengaruh Kompres Hangat Terhadap Nyeri Asam Urat Pada Kelompok Kontrol

\begin{tabular}{lllll}
\hline Variabel & Mean & SD & Nilai t & Sig. (2-tailed) \\
\hline Pre kelompok control & 5.2 & 1.5 & 15.588 & 0.0001 \\
Post kelompok control & 3.4 & 1.633 & 15.588 & 0.0001 \\
Rata-rata penurunan nyeri & 1.8 & 0.577 & 9.899 & 0.0001 \\
\hline
\end{tabular}

Berdasarkan uji statistik dengan menggunakan paired t test kelompok kontrol pada pengukuran nyeri asam urat didapatkan nilai rata-rata nyeri sebelum dilakukan pemberian kompres air hangat sebesar 5.20, dan nilai rata-rata setelah dilakukan pemberian kompres air hangat adalah 3.40, artinya ada perbedaan pengukuran nyeri asam urat sebelum dan setelah pada kelompok kontrol. Nilai signifikansi dari perbedaan tersebut didapatkan $p$ $(0.0001)<\alpha(0.05)$ pada taraf kepercayaan 95\%. Maka dapat disimpulkan Ada Pengaruh Kelompok Kontrol Terhadap Nyeri Asam Urat Di Posyandu Melati Desa Candisari Kabupaten Grobogan. 
Berdasarkan hasil statistik didapatkan nilai t untuk kelompok kontrol sebelum dan setelah perlakuan sebesar 15.588 dan nilai t untuk rata-rata penurunan nyeri kelompok kontrol sebesar 9.899. Berdasarkan uji statistik dengan menggunakan uji independent t test diperoleh nilai rata-rata penurunan nyeri asam urat pada kelompok kontrol sebesar 1.80

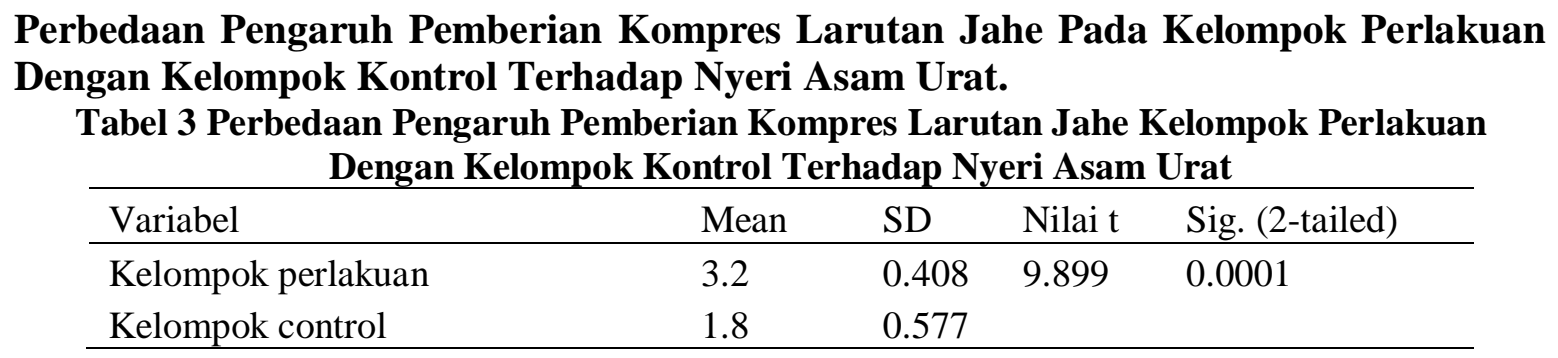

Berdasarkan uji statistik dengan menggunakan independent $t$ test diperoleh nilai rata-rata penurunan nyeri asam urat pada kelompok perlakuan sebesar 3.20 dan kelompok kontrol sebesar 1.80, artinya ada penurunan nyeri 1.40. Berdasarkan Nilai signifikansi didapatkan $p(0.0001)<\alpha(0.05)$ pada taraf kepercayaan 95\%. Berdasarkan hasil statistik didapatkan nilai $\mathrm{t}$ sebesar 9.899, yang berarti dalam pemberian kelompok perlakuan kompres larutan jahe dan kelompok kontrol memiliki perbedaan sebesar 9.899. Maka dapat disimpulkan Ada Perbedaan penurunan nyeri kelompok perlakuan dan kelompok kontrol penderita Nyeri Asam Urat.

\section{Pembahasan}

\section{Analisa Univariat}

Nyeri responden pada kelompok perlakuan dan kelompok kontrol sebelum diberikan kompres larutan jahe dan kompres air hangat.

Berdasarkan hasil penelitian menunjukkan bahwa semua sampel penelitian menyatakan sebelum pemberian kompres larutan jahe dan kompres air hangat responden merasakan nyeri pada bagian tangan, lutut, dan punggung yang berlebihan. Sebelum diberikan perlakuan kompres larutan jahe dan kompres air hangat sebagian besar mengalami nyeri yaitu 8 (nyeri hebat), dan yang paling kecil adalah 3 (nyeri ringan) dengan rata-rata didapatkan hasil skala nyeri 5-6 (nyeri sedang). Nyeri adalah rasa tidak nyaman pada fisik yang diduga disebabkan oleh kerusakan jaringan baik sengaja maupun tidak disengaja (International Association For The study Of Pain, 2015).

Menurut Badan Statistik (2016), rata-rata usia lanjut sudah purna tugas dan lebih sering menjalankan aktivitas dalam pekerjaan rumah tangga. Ada beberapa faktor yang mempengaruhi nyeri antara lain usia, kelemahan, fungsi neurologis, perhatian, pengalaman sebelumnya, faktor spritual, kecemasan, teknik koping dan arti dari nyeri (Potter \& Perry, 2005).

Penelitian ini diperkuat oleh Rusnoto (2015), penderita nyeri asam urat berdasarkan skala nyeri sebelum dilakukan kompres hangat memakai jahe terdapat hasil dari seluruh jumlah 30 responden rata-rata mengalami sklanya nyeri 6 (nyeri sedang) dengan skala tertinggi 8 ( nyeri berat) dan skala terkecil 3 ( nyeri ringan ). 
Nyeri responden pada kelompok perlakuan dan kelompok kontrol setelah diberikan kompres larutan jahe dan kompres air hangat.

Hasil menunjukkan bahwa pemberian kompres larutan jahe dan kompres air hangat dapat membantu fungsi nyeri sendi pada penderita asam urat. Setelah dilakukan pemberian kompres larutan jahe dan kompres air hangat didapatkan hasil skala nyeri yaitu dengan rata-rata 2-3 (nyeri ringan). Setelah diberikan kompres larutan jahe dan kompres air hangat terdapat penurunan pada nyeri responden karena responden memiliki semangat untuk sembuh tanpa mengeluarkan biaya yang mahal dan bahan-bahan untuk pengompresan yang digunakan sangat mudah didapat di dapur responden.

\section{Analisa Bivariat \\ Pengaruh Pemberian Kompres Larutan Jahe Terhadap Nyeri Asam Urat Kelompok Perlakuan.}

Yang dilakukan peneliti dengan menggunakan uji normalitas dengan shapiro wilk pada nyeri sebelum kelompok yang diberikan kompres larutan jahe $p(0,103)>\alpha(0,05)$, dan nyeri setelah pemberian kompres larutan jahe $p(0,086)>\alpha(0,05)$, keduanya berdistribusi normal. Karena distribusi data normal, maka untuk mengetahui signifikansi penurunan nyeri sebelum dan setelah diberikan kompres larutan jahe menggunakan uji paired t-test. Berdasarkan uji statistik dengan menggunakan paired t test kelompok perlakuan pada nyeri asam urat didapatkan nilai rata-rata nyeri sebelum dilakukan pemberian kompres larutan jahe adalah 5.64 (nyeri sedang), dan nilai rata-rata setelah dilakukan pemberian kompres larutan jahe adalah 2.44 (nyeri ringan), artinya ada perbedaan nyeri sebelum pemberian kompres larutan jahe dan nyeri setelah pemberian kompres larutan jahe. Nilai signifikansi dari perbedaan tersebut didapatkan $p(0.0001)<\alpha$ (0.05) pada taraf kepercayaan $95 \%$.

Pengaruh kompres jahe bisa mengurangi rasa nyeri pada sendi karena mimiliki sifat pedas, pahit, dan aromatik dari olerasin seperti zingerol, gingerol, dan shagaol. Olerasin memiliki potensi anti inflamsi, analgetik, dan antioksidan yang kuat sehingga dapat menghambat sintesis prostag glandin yang dapat mengurangi nyeri atau radang pada sendi.

Jahe sendiri mempunyai kegunaan yang cukup beragam, antara lain sebagai rempah, minyak atsiri, pemberi aroma, ataupun sebagai obat (Bartley \& Jacobs, 2012). Jahe dapat mengurangi nyeri dan kekakuan pada satu atau lebih sendi, untuk penangannya asam urat dosis yang dianjurkan 510-1000 mg/hari serbuk jahe. Pemberian ekstrak jahe 1gr/hari selama 4 minggu lebih efektif dibandingkan dengan placebo dan sama efektifnya dengan ibuprofen dalam meredakan nyeri (Learh \& Kumar, 2008). Ketika pemberian terapi diberikan, responden tampak begitu rileks dan menikmati sensai hangat pada lokasi nyeri yang dirasakan. Perilaku yang sebelumnya tampak gelisah, sering mengadu kesakitan berubah menjadi tenang, diam tidak banyak mengadu seakan akan mereka sedang berkonsentrasi terhadap sensasi hangat yang dirasakan. Penelitian ini diperkuat oleh Putri, Devi, Noor (2017), didapatkan hasil bahwa pemberian kompres hangat memakai jahe merah dapat meringkankan skala nyeri pada pasien asam urat.

Penelitian lain yang dilakukan oleh Samsudin (2016), didapatkan hasil bahwa terdapat pengaruh yang signitifikan pemberian kompres hangat memakai parutan jahe merah (Zingiber Officinale Var Rubrum) terhadap penurunan skala nyeri pada pasien asam urat. Berdasarkan hasil uji Wilcoxon nilai sig atau $0.003(\mathrm{p}<0.05)$ 


\section{Pengaruh Kelompok Kontrol Terhadap Nyeri Asam Urat Di Posyandu Melati Desa Candisari Kabupaten Grobogan.}

Yang dilakukan peneliti menggunakan uji normalitas dengan shapiro wilk pada nyeri sebelum asam urat kelompok kontrol diperoleh $p(0.117)>\alpha(0.05)$, dan nyeri setelah asam urat kelompok kontrol diperoleh $p(0.077)>\alpha(0.05)$, keduanya berdistribusi normal. Berdasarkan uji statistik dengan menggunakan paired $t$ test kelompok kontrol pada pengukuran nyeri asam urat didapatkan nilai rata-rata nyeri sebelum dilakukan pemberian kompres air hangat sebesar 5.20 (nyeri sedang), dan nilai rata-rata setelah dilakukan pemberian kompres air hangat adalah 3.40 (nyeri ringan), artinya ada perbedaan pengukuran nyeri asam urat sebelum dan setelah pada kelompok kontrol. Nilai signifikansi dari perbedaan tersebut didapatkan $p(0.0001)<\alpha(0.05)$ pada taraf kepercayaan 95\%, Kompres hangat juga dapat menurunkan nyeri pada pasien asam urat. Proses tersebut akan menurunkan transmisi nyeri melalui serabut $\mathrm{C}$ dan delta $\mathrm{A}$ sehingga dapat menimbulkan gerbang tertutup dari nyeri.

Menurut Mutiara, Pratiwi (2017), ketika responden mengalami nyeri dimana pada saat kompres diletakkan ditempat yang nyeri maka rasa panas tersebut akan berpindah ketubuh atau kulit, sehinga terjadilah proses konduksi yang terjadi pada tubuh sehingga menyebabkan vasodilatasi pembuluh darah dan menurunkan otot yang tegang agar otot menjadi relaksasi dan rasa nyeri akan berkurang. Adanya $\mathrm{O} 2$ dan $\mathrm{CO} 2$ meningkat serta penurunan $\mathrm{pH}$ darah yang akan merangsang reseptore sensorik sehingga nyeri tidak diteruskan ke otak.

\section{Perbedaan Pengaruh Pemberian Kompres Larutan Jahe Dengan Kelompok Kontrol Terhadap Nyeri Asam Urat.}

Distribusi data normal, maka untuk mengetahui perbedaan perubahan nyeri kelompok perlakuan dan kelompok kontrol menggunakan uji independen $t$ test, diperoleh nilai rata-rata penurunan nyeri asam urat pada kelompok perlakuan sebesar 3.20 dan kelompok kontrol sebesar 1.80 artinya ada penurunan nyeri 1.40 (nyeri ringan) antara penurunan kelompok perlakuan dengan kelompok kontrol. Berdasarkan Nilai signifikansi didapatkan $p(0.0001)<\alpha(0.05)$ pada taraf kepercayaan 95\%.

Penelitian ini diperkuat oleh Putri Rima (2018) Di dapatkan hasil uji MannWhitneypada 2 kelompok didapatkan p-value 0.005 rata-rata penurunan nyeri pada kelompok intervensi 2.06 dan kelompok kontrol 1.06, bermakna terdapat perbedaan efektifitas terapi kompres jahe merah dan kompres hangat biasa terhadap penurunan nyeri pada pasien asam urat.

\section{SIMPULAN}

Berdasarkan hasil penelitian dan pembahasan bahwa ada pengaruh pemberian kompres larutan jahe (zingiber officinale roscoe) terhadap nyeri asam urat. Disarankan bagi penderita asam urat untuk melakukan kompres larutan jahe di rumah dengan menggunakan alat-alat sederhana dan terjangkau oleh semua lapisan masyarakat, dan tindakan ini merupakan cara alternative untuk menurunkan nyeri. 


\section{DAFTAR PUSTAKA}

Alifiasari, D., (2011). Komplikasi asam urat. http//e-bookspdf.org.

Arya, RK \& Jain, V. 2013. Osteoarthritis of the Knee Joint. Journal Indian Academy of Clinical Medicine. Vol 14. No 2. Page 154-162.

Badan Pusat Statistik. (2016). Statistik Indonesia 2015.Jakarta: BPS

Bartley, J. And A. Jacobs. (2012). Effect of drying on flavour compounds in australiangown ginger (zingiber officinale). Journal of the science of food and agriculture. 80: 209-215.

Dalimartha, S. (2010). Resep Tanaman Obat Untuk Asam Urat. Jakarta: Penebar Swadaya.

Hamijoyo, L. (2014). Apakah nyeri sendi saya akibat asam urat? Kenali Gout. Perhimpunan Reumatologi Indonesia.

Handayani dan Wahyuni. 2012. Hubungan Dukungan Keluarga dengan kepatuhan lansia dalam menikuti Posyandu Lansia di Posyandu Lansia. Jurnal Kesehatan.

The International Association For The Study Of Pain Definition Of Pain: As Valid In 2018 As In 1979, But In Need Of Regularly Updated Footnotes. https://www.ncbi.nlm.nih.gov/pmc/articles/PMC5902252

Jaliana. dkk, (2018). Faktor-Faktor Yang Berhubungan Dengan Kejadian Asam Urat Pada Usia 20-44 Tahun Di Rsud Bahteramas Provinsi Sulawesi Tenggara Tahun 201. Jurnal ilmiah Mahasiswa Kesehatan masyarakat. Vol.3/No.2/april 2018;ISSN 2502$731 x$

Leach, MJ dan Kumar, S. (2008). The Clinical Effectiveness of Ginger (Xinger Officinale) in adults with Osteoarthtritis, International Journal Ofevidance Based Health Centre, Diakses 26 Agustus 2015, Proquest Database.

Mutiara, H. Pratiwi. L. 2017. Pengaruh Jahe terhadap Nyeri saat Menstruasi. Bagian Parasitologi, Fakultas Kedokteran, Universitas Lampung Fakultas Kedokteran, Universitas Lampung

Nengsi, S. W. dkk, (2014). Gambaran asupan purin, penyakit artritis gout, kualitas hidup lanjut usia di kecamatan tamalanrea. Hal 4-5. Diakses pada tanggal 27 April 2019. www.adln.lib.unhas.ac.id.go

Nopik W, (2013). Pengaruh pemberian rebusandaun sirsak terhadap nyeri pada penderita gout. Dikeluarkan Genuk Barat Kecamatan Ungaran Barat Kabupaten Semarang.

Prasetyo, S. N. (2010).Konsep dan Proses Keperawatan Nyeri. Yogyakarta: Graha Ilmu. Price,W.L (2012). Patofisiologi Konsep Klinis proses-proses penyakit ed.6.Jakarta .EGC

Potter, P.A, Perry, A.G. (2006). Buku Ajar Fundamental Keperawatan : Konsep, Proses, Dan Praktik.Edisi 4.Volume 1.Alih Bahasa : Yasmin Asih, dkk. Jakarta : EGC

Putri, Devi,Noor (2017). Pengaruh Pemberian Kompres Jahe Terhadap Intensitas Nyeri Gout Artritis Pada Lansia Di Pstw Budi Sejahtera Kalimantan Selatan. Dunia $\begin{array}{lllll}\text { Keperawatan. Jurnal keperawatan dan kesehatan Vol.5 No.2. } & \text {. }\end{array}$ https://ppjp.ulm.ac.id/journal/index.php/JDK/article/view/4112

Putri Rima. (2018). Evaluasi Pelaksanaan Pelayanan Kefarmasian Di Apotek Wilayah Kota Tegal Tahun 2018. http://ejournal.poltektegal.ac.id/index.php/parapemikir

Rustonto, Cholifah N, Retnosari I. (2015). Pemberian Kompres Hangat Memakai Jahe Untuk Meringankan Skala Nyeri Pada Pasien Asam Urat di Desa Kedungwungu Kecamatan Tegowanu Kabupaten Grebongan. www.digilib.stikesmuhpkj.ac.idDiakses 2 April 2016 pada pukul 13.05 WITA. 
Samsudin (2016).Pengaruh Pemberian Kompres Hangat Memakai Parutan Jahe Merah (Zingiber Officinale Roscoe Var Rubrum) Terhadap Penurunan Skala Nyeri Padapenderitagout Artritis Di Desa Tateli Dua Kecamatan Mandolang Kabupeten Minahasa.Jurnalkeperawatanhttps://ejournal.unsrat.ac.id/index.php/jkp/article/view/ $\underline{12128}$

Sopiyudin M. (2014). Statistik Untuk Kedokteran dan Kesehatan: (6th ed.). Jakarta: Epidemiologi Indonesia

Sugiono (2012).Metode Penelitian Pendidikan Pendekatan Kuantitatif, Kualitatif, Dan $R \& D$. Bandung. Alfabe 